\title{
Rules for the Exploitation of Jointly Owned Copyright and Patent in Ethiopia
}

\author{
Misganu Degif Ergne \\ School of Law, Wolkite University, PO. Box 07, Wolkite, Ethiopia
}

\begin{abstract}
Intellectual property rights can, as any property rights, be owned by more than one person jointly. Such joint ownership of intellectual properties may arise either from joint creation, inheritance, court decision or agreement of the joint owners. Since joint ownership of intellectual property involves more than one person sharing undivided interest over such rights, special attention should be given to rules governing the exploitation of such rights by joint owners. The relationship among joint owners in the exploitation of such rights may be determined either by the law or agreement of the joint owners. In principle the joint owners are at liberty to determine the manner of exploiting jointly owned intellectual property rights among themselves. However, in the absence of an agreement among the joint owners on how to exploit the jointly owned intellectual property rights, the default provisions of the laws are applicable to such situations. Both the Ethiopian copyright and patent laws, while recognizing joint ownership of copyright and patent respectively, are failed to provide for default rules for the exploitation of such rights among the joint owners in case the latter have failed to reach in to an agreement to this end. Nor did they make an explicit reference to the provisions of the Ethiopian civil code on joint ownership of things so that they would be made applicable mutatis mutandis to the jointly owned copyright and patent. This work is inspired by the literature gap existing in this area particularly in relation to rules governing the exploitation of jointly owned copyright and patent. A doctrinal research approach is employed in the analysis of the provisions of the copyright and patent laws and the civil code of Ethiopia in light of the laws other states. This article, in the absence of an agreement among the joint owners, is arguing for the applicability of the provisions of the Ethiopian civil code on joint ownership of things mutatis mutandis to the exploitation of jointly owned copyrights and patents. It also recommends, after the thorough examination of the relevant provisions of both the copyright and patent laws of Ethiopia, a law reform measures to be undertaken by the legislature such as the need for setting a clear preconditions to be fulfilled in order to consider persons as a joint creator of copyright and patent and the regulation of joint ownership of copyright and patents under the respective laws of copyright and patent.
\end{abstract}

Keywords: Agreement, Rules, Copyright, Patent, Exploitation, Joint ownership, Ethiopia

DOI: $10.7176 / \mathrm{DCS} / 10-7-04$

Publication date:July $31^{\text {st }} 2020$

\section{Introduction}

Human intellect is recognized as one of the sources of private property under the domestic laws of sates and international legal instruments and accordingly protection is given to it. Ethiopia is no exception to that as the FDRE Constitution and other subordinate laws have recognized human intellect as one of the sources of private property and protection is provided thereto. Intellectual properties (IP) as a subset of the broader categories of property rights are subject to the general rules governing property rights. Particularly rules governing the exploitation of property rights in general, without prejudice to the special character of intellectual property, are applicable to the exploitation of intellectual properties.

This work is devoted to the examination of the rules for exploitation of jointly owned copy rights and patents in Ethiopia. In the first section, as an introduction and a stepping stone for subsequent discussions, the meaning and sources of joint ownership of Intellectual property rights (IPRs) in general and copy right and patent in particular within the context of property right are discussed. Under the second section, the concept of exploitation is discussed within the context of IP and types of exploitation such as direct and indirect exploitation of IPs. The third section has two sub-sections. The first sub-section briefly introduces the experiences of some states on rules for the exploitation of jointly owned copy rights and patents. The second sub-section, which is the main part of this work, will examine the rules for exploitation of jointly owned copy rights and patents in Ethiopia. Finally, conclusions and recommendations are presented under the fourth section.

\section{Section One- Meaning and Sources of Joint Ownership of Intellectual Property Rights (IPRs) 1.1. Meaning of joint of ownership of IPRs}

Joint ownership is a situation in which two more persons have proprietary shares of an asset. Black's Law dictionary defines Joint ownership as "undivided ownership shared by two or more persons." Here two points are worth mentioning in defining joint ownership. One is the plurality of parties involved in a joint ownership. As

\footnotetext{
${ }^{1}$ Bryan A. Garner (ed.) Black's Law Dictionary (9 $9^{\text {th }}$ edn, Thomson Reuters 2009) p.1215
} 
the name speaks, joint ownership involves a joint exercise of ownership right by more than one person. The plurality of parties in a joint ownership has its own implication on the exercise of rights which the joint ownership confers on joint owners. The other is the indivisible/ inseparable nature of shares each joint owners have on the subject matter over which ownership right is exercised. The right is an undivided unity, which is vested at the same time in more than one person. ${ }^{1}$ Joint owners have an undivided share on the subject matter over which ownership right is exercised. That is each joint owners have a share on the totality of the subject matter of ownership. As far as the joint ownership continues to exist, none of the joint owners can claim their share on a certain part of the subject matter of the right since each joint owner have a share on every part thereof irrespective of the amount of share each joint owners have. ${ }^{2}$

Joint ownership in the context of IP, is the ownership of an intellectual property right by more than one person. The source of joint ownership of an IP (which will be discussed later) might be either an agreement or collaborative effort in the creation of such rights by joint owners. As discussed above, whatever their contribution might be, each joint owners have an undivided right over the IP concerned. The Ethiopian Copy Right and Neighboring Right Protection Proclamation (here in after called the copy right proclamation) defines a work of joint ownership as " $a$ work to the creation of which two or more authors have contributed, provided that the work does not qualify as a 'collective work'..." As per this definition, a joint work is understood to be the result of creative contribution of two or more authors. Accordingly, authorship is required in order to be a joint owner of the work. A 'work' on the other hand is defined as "a production in the literary, scientific and Artistic fields."

However, a note must be made that joint ownership of work does not necessarily results in a joint ownership of copy right as it is possible that ownership of copy right over a work might be held by a person other than the author of the work. An owner of a copy right may be the author him/herself or another person (legal or physical) on whom the ownership of an economic right is vested in. ${ }^{5}$ Third parties may acquire the economic right over the work on the basis of either the law or through a contractual agreement concluded with the author of the work (this will be elaborated later). At this juncture it is necessary to make a distinction between an author of the work and an owner of copyright over the work. If a work is created by the joint efforts (contribution ) of more than one person and the economic right over that work is vested in those creators(authors), this will be a case for joint ownership of copy right. Another case for joint ownership of copy right is where the economic right over a work is vested in more than one person even though such persons are not the authors of that work.

Joint ownership of patent is a situation in which two or more persons have an ownership over a single invention. The Proclamation Concerning Inventions, Minor Inventions and Industrial Designs (herein after called patent proclamation) has not defined joint ownership of a patent. It rather tells us how a joint ownership of patent could arise. ${ }^{6}$ This could happen either through a joint creative effort made by more than one person or in the absence of an express term to the contrary, where an employee make use of the resources of the employer in addition to his/her personal contribution in the creation of the invention. Joint ownership of patent could also come in to picture through contractual arrangement when a patent is transferred to more than one person. ${ }^{7}$ So a joint ownership, in the context of patent is, an ownership of a single patent by more than one person irrespective the share each joint owner have over the invention concerned.

\footnotetext{
1 John W. Salmond, Jurisprudence or The Theory of The Law (10th ed. Stevens \& Haynes London 1902) P. 277

${ }^{2}$ Ibid. Salmomd reiterates that "it is not correct to say that a right owned by co-owners is divided between them, each of them owning a separate part. The moment the parties have started to own the right separately, this brings the joint ownership to an end."

3 Copyright and Neighboring Rights Protection Proclamation, 2004, Proc.No.410, Federal Negarit Gazzeta, 10 ${ }^{\text {th }}$ year No.55. Article 2(29). Collective works on the other hand are defined as "a literary and artistic work created by two or more physical persons at the initiative and under the direction of a person with the understanding that it will be disclosed in the name of the latter person without indicating the identity of the contributor" See Id. Article 2(5). Whereas the original ownership of a joint work belongs to co-authors of the work, the original ownership of a collective work belongs to the person at whose initiative and under whose direction the work has been created. Id. Article 21(2,3) see also Fikremarkos Merso, The Ethiopian Law of Intellectual Property Rights: Copyrights, Trademarks, Patents, Utility Models and Industrial Designs, A Textbook (Addis Ababa: The American Bar

Association, 2012) he argues, regarding the difference between collective and joint works, that "though not clear from the copyright proclamation, the important difference between a joint work and a collective work appears to be the nature and quality of the contribution of each."

${ }^{4}$ Id. Article 2(30). The lists of works mentioned under this sub-article are illustrative and includes: a) books, booklets, articles in reviews and newspaper, computer programs; b) speeches, lectures, addresses, sermons, and other oral works; c) dramatic, dramatico-musical works, pantomimes, choreographic works, and other works created for stage production; d) musical compositions; e) audiovisual works; f) works of architecture; g) works of drawing, painting, sculpture, engraving, lithography, tapestry, and other works of fine arts; h) photographic works; i) illustrations, maps, plans, sketches, and three dimensional works related to geography, topography, architecture or science.

${ }^{5}$ Id. Article $2(16)$

${ }^{6}$ Proclamation Concerning Inventions, Minor Inventions and Industrial Design,1993, Proc.No.123, Negarit Gazzeta, 54 ${ }^{\text {th }}$ year No.25 Article $7(2,5)$. The provisions of the proclamation dealing with patent of introduction, minor inventions and industrial design provides for the mutatis mutandis application of section of the proclamation dealing with patent (inventions) to patent of introduction, minor inventions and industrial design respectively. See Id. Article 28, 45 and 51. Accordingly, the discussions made in this work with respect to patent are equally applicable to the jointly owned patent of introduction, minor inventions and industrial designs.

${ }^{7}$ Id. Article 6
} 


\subsection{Sources of joint ownership of IPRs}

Joint ownership of IP may originate from various sources such as the provisions of the law, contractual agreement (sale, donation), inheritance and judicial decisions. For the purpose of this work, sources of joint ownership of IPRs are classified in to three broad categories: laws, contractual agreements and others. The following is a brief discussion on each category of sources of joint ownership.

\section{a) Law as a source of joint ownership of IPRs}

The provision of the law is one of the notable sources of joint ownership of property right in general and intellectual properties in particular. Joint ownership arises from the provisions of the law when the law provides that a certain proprietary interests are to be owned by more than one person outside the context of contractual arrangement among the joint owners. Joint ownership of IP arises by law when a work is jointly developed by several partners and their respective contribution to the final work cannot be ascertained, or the work (results) is by nature indivisible. ${ }^{1}$ The law set forth conditions up on the fulfillment of which a certain proprietary interests are considered to be owned jointly by more than one person. For instance the law, in the field of intellectual property, set forth joint creation as a pre-condition for the emergence of joint ownership of intellectual property. As discussed in the preceding section of this work, the Ethiopian Copy right proclamation requires a joint creative contribution by more than one author for a work to be considered as joint work. ${ }^{2}$ Similarly under the patent proclamation, a joint invention by more than one person is required for a joint ownership of patent. ${ }^{3}$ No other conditions, other than joint authorship in case of copy right and joint invention in case of patents, are required under the copy right and patent laws of Ethiopia for a joint ownership of work and joint ownership of patent respectively.

The copy right and patent laws of other state such the US requires more than mere joint creation for a work to be considered as jointly owned by more than one person. Under the US Copy Right Act (1976), two conditions are necessary on top of joint creation, for a work to be considered as joint work thereby resulting in a joint ownership. ${ }^{4}$ These are contribution and intention to create a joint work. The contribution of each joint owner should be of copyrightable in itself..$^{5}$ Accordingly, the mere supply by one party of non-copyrightable facts or research nor developing by one party of only the general idea for the plot of a novel or a play, and reveals it to another party who then executes the idea by crafting the actual prose will not result in a joint work. ${ }^{6}$ The contribution by each joint owner need not necessarily be equal as long as it is a copyrightable expression. ${ }^{7}$

The joint creation must also be accompanied by an intention on the part of each joint owner to create a joint work. It is the intent of the parties at the time a work is created that determines whether it is a joint work. ${ }^{8}$ Even if several works created at a different period of time are brought together to form a single copyrightable work, this could also be considered as a joint work if the intention of each joint owner is creating a single joint work by merging his/her contribution with others' contribution. ${ }^{9}$ Similarly under the relevant sections of the United States Code governing joint invention, contribution and some form of collaborations are required for an invention to be considered as jointly owned by more than one person. ${ }^{10}$ The contribution need not be equal and need not also be to every part of the subject matter of the invention. Some form of connection among the inventors is also necessary as individuals who are completely ignorant of what each other has done cannot be considered joint inventors. ${ }^{11}$

The Ethiopian copy right and patent proclamations, while providing a case for joint ownership of a work and patent respectively, are failed to regulate some of the important aspects of such joint ownership. Particularly the law has failed to regulate the nature and amount of contribution required of a person in order to consider that person as joint owner of the resulting work. Accordingly, it is not clear under the copy right and patent laws of Ethiopia that what amount of contribution is necessary for a person to be considered as joint owner of a copy right or a patent. In the absence of an agreement to the contrary, the law is not clear on the amount share each joint

\footnotetext{
${ }^{1}$ European IPR Helpdesk, IP Joint Ownership, Fact Sheet 2015 available at $<$

www.iprhelpdesk.eu>

${ }^{2}$ Art.2(29) cum 21(2) of copy right proclamation

${ }^{3}$ Art. 7(2,5) of patent proclamation

417 USC Section 101.U.S. Copyright Act (1976) available at $<$ https://codes.findlaw.com/us/title-17-copyrights/17-usc-sect-101.html> defined a joint work as "a work prepared by two or more authors with the intention that their contributions be merged into inseparable or interdependent parts of a unitary whole." See also section 201(a) of U.S. Copyright Act (1976) which states that "the authors of a joint work are co-owners of copyright in the work."

5 Roger E. Schechter and John R. Thomas, Intellectual Property: the Law of Copyrights, Patents and Trademarks (Hornbook Series, west group 2003) p.102

${ }^{6}$ Ibid.

${ }^{7}$ Ibid.

${ }^{8}$ Deborah E. Bouchoux, Intellectual Property: The Law of Trademarks, Copyrights, Patents, and Trade Secrets( $4^{\text {th }}$ edition Delmar, Cengage Learning 2012) P. 229

${ }^{9}$ Ibid.

1035 U.S. Code $\S 116$ (a) available at < https://www.law.cornell.edu/uscode/text/35/116> states that "inventors may apply for a patent jointly even though (1) they did not physically work together or at the same time, (2) each did not make the same type or amount of contribution, or (3) each did not make a contribution to the subject matter of every claim of a patent."

${ }^{11}$ Deborah E. Bouchoux cited at note 16, p. 405
} 
owner presumed to have on a jointly owned work unless recourse is made to the provisions of the Ethiopian civil code governing joint ownership, which presumes equality share. ${ }^{1}$ The other important aspect of joint ownership of IP which the law should have regulated is the role of parties' intention in the creation of a joint work or joint invention. It is not clear whether an intention to create a joint work is a necessary requirement or merely an accidental collaboration suffices for a work to be considered as jointly owned by more than one person.

Another scenario in which joint ownership of IP could arises from the provisions of the law is where such rights are devolved on the heirs or legatees of a deceased person, who have been enjoying such rights prior to his/her death, through the machinery the law of intestate succession. This happens when the deceased has died intestate or has made a will with respect only to some aspects of the right and left the other aspect of the right unregulated or the will made by the deceased is found to be invalid under the law. ${ }^{2}$ In that case the law steps in and determines who should be the successor of the right (including IP) of the deceased person. Accordingly, joint ownership of IP among the heirs or legatees arises if two or more heirs or legatees are found to be entitled under the law to inherit the IP rights of the deceased.

\section{b) Contractual agreements as a sources of joint ownership of IPRs}

Contractual agreements are the other sources of joint ownership of IP. Contractual agreements, as long as they are made in accordance with the mandatory provisions of the law, are the most important sources of a joint ownership of IPs. Contractual agreements can serve as sources of joint ownership of IPs either in the original creation of the work or through the transfer of the work after the work is created. In the former case, an agreement could be reached between the author and employer or a person having commissioned the work in favor of the joint ownership of the resulting work between the author and employer or person commissioning the work. Article 21(4) of the copy right proclamation provides that "where the work is a work created by an author employed or Commissioned by a person in the course of his employment or contract of service, unless agreed otherwise, the original owner of the rights shall be the employer or the person who commissioned the work" The work that may have been resulted from employment relationship or contract of services, the ownership of which the law ascribes solely to the employer or the person having commissioned the work, might be owned jointly by the author and employer or person having commissioned the work through an agreement to this effect. Accordingly, the author and the employer or person having commissioned the work can perfectly agree in advance that the work that may have been resulting from employment relationship or the contract of service will be owned jointly by the author and the employer or person having commissioned the work. A similar provision is found under the patent proclamation which envisages a possibility that an invention that may have been resulted from a contract of employment or a contract of service, which in the absence of an agreement to the contrary belongs to the employer or person having commissioned the work, could be owned jointly by the employee or person commissioned and employer or person having commissioned the work through an agreement made in advance to this effect. ${ }^{3}$ This $^{\text {is }}$ how joint ownership of IP has found its way in to the contractual agreements made in advance to allocate the ownership of the resulting IP to more than one person even before its creation.

Contractual agreements for the transfer of rights over IP to more than one person are also the other sources of joint ownership of IP. In principle, the original ownership right of copyrights and patents belongs to the respective author(s) and inventor(s) of such copy right and patent. ${ }^{4}$ However, such rights can be transferred to third parties as they are equally transferable as any other property rights. Both the copy right and patent proclamation provides for the transfer of the ownership of copyright and patent to another person through contractual agreement. ${ }^{5}$ Accordingly, copyright or patent which is owned by a single person can be transferred through contractual agreement, such as assignment or donation, to more than one person and thereby joint ownership of copyright or patent comes in to picture. So the transfer of copyright or patent either from original owner or a person who have acquired such rights from the original owner to more than one person through contractual agreement is the other case for joint ownership of copyrights or patents within the realm of contractual arrangement.

The distinction between the two cases for joint ownership of IP in general and copyright and patent in particular discussed above within the context of contractual agreement is that while in the former case, contractual agreements are used to create the copyrights or patent itself under the joint ownership of the author or inventor and the employer or the person having commissioned the work, in the latter case contractual agreements are used

\footnotetext{
${ }^{1}$ Article 1259 of the civil code of Ethiopia, See also Article 7(5) of the patent proclamation, in the absence of an agreement to the contrary, equality of share is recognized on inventions which are not resulted in the course of employment relationship or commissioned work and rather resulting from both the personal contribution of the author and the resources, data, means, materials or equipment of the employer. Unless the joint owners agreed otherwise, it is not clear what proportion each joint owner of the inventions will have in other cases of joint ownership especially in case of joint inventions.

${ }^{2}$ The Civil Code of The Empire of Ethiopia, 1960, Proc. No.165, Negarit Gazzeta, $19^{\text {th }}$ year No.2, Art. 829 cum Article 863-874. Courts may in particular invalidate testamentary provisions where such provisions are found to be illegal, immoral, impossible, made under the influence of violence or made by notoriously insane person. See also Article 8 and 20(1) of the copy right and Article 6 of the patent proclamation.

${ }^{3}$ See Article 7(3) of patent proclamation

${ }^{4}$ See Article 7(1) of patent proclamation and Article 2(16) cum 21(1) of copy right proclamation

${ }^{5}$ See Article 6 of patent proclamation and Article 2(16) of copy right proclamation
} 
to transfer the copyright or patent which is already in existence to more than one person thereby joint ownership of IP arises.

\section{c) Other Sources of Joint Ownership of IPRs}

In this sub-topic, joint ownership of IPs other than laws and contractual agreements particularly inheritance and court decisions as sources of joint ownership of IP will be discussed.

Inheritance can be another source of joint ownership of IPs. Inheritance serves as a means for the transfer of property rights and of course obligations of a deceased person to one or more living persons up on the death of the former. ${ }^{1}$ In this regard J.W. Salmond states that "The rights which a dead man thus leaves behind him vest in his representative. They pass to some person whom the dead man, or the law on his behalf, has appointed to represent him in the world of the living." 2

However, not all rights of a deceased person are inheritable. ${ }^{3}$ The proprietary rights of a deceased person, which are inheritable in their nature, may transfer to a living person(s) either through a will made by the deceased during his/her life time or through the law of intestate succession.

The deceased person, through the will duly declared during his/her life time, can validly determine how and by whom his /her rights should be enjoyed up on his/her death. Accordingly, the deceased may transfer his/her property rights (including IPs) through a legally made will to one or more living person(s). The Ethiopian copyright and patent proclamations have clearly recognized the right of the owners of copyright and patent to transfer their rights through inheritance to others. Under the copyright proclamation, both the economic rights (which may belongs either to the author or another person where such rights are vested in a person other than the author) and moral rights of the authors are transferable through inheritance to the heirs or legatees of the author or a person in whom the economic rights are vested in up on his/her the death. ${ }^{4}$ The patent proclamation on the other hand provides that "Any patent or application for a patent may be transferred by sale or inheritance or any other means in accordance with the law." Not only patents but also an application for patents can be transferred through sale, inheritance or other means such as donation to others.

Accordingly, joint ownership of IP particularly copyright and patent may arises where such rights are transferred in the form of inheritance in accordance with the will made by the right holder to more than one person.

Another source of joint ownership of IPRs is an attachment and transfer of businesses to creditors by way of fulfillment of the obligations secured where businesses comprising intellectual property as an element are mortgaged as a security for the performance of obligations and the debtor has failed to perform his/her obligations as agreed. Businesses may consist of incorporeal elements such as copyright, trade mark, patent and trade name. ${ }^{6}$ Such businesses may be mortgaged in order to secure the performance of an obligation by the owner of such businesses. ${ }^{7}$ In case the debtor having mortgaged his/her business is failed to perform his/her obligation, the law authorizes the creditor to move the court to order attachment of the business with a view to causing it to be sold by auction. ${ }^{8}$ In such cases two or more persons may acquire the business with its copyright or patent and thereby results in a joint ownership of IP particularly copyright or patent. An attachment of IPR by the decision of a court and subsequent transfer of such rights to more than one person can also be another source of joint ownership of IPR in countries where the legal regime provides for the establishment of a security interest on IPRs. In Ethiopia, however, owing to lack of proper legal frame work for the formation of a security interest on IPRs in general and copyright and patent in particular, it is arguable whether or not a security interest on IPRs could be established validly. ${ }^{9}$ Consequently, it is difficult to say that an attachment of IPRs through court order where the debtor (pledgee) failed to perform his/her obligation and subsequent transfer of such rights to more than one person can be a source of joint ownership of IPRs in Ethiopia.

\section{Section Two: The Meaning and Types of Exploitation of IPRs}

In the preceding section of this work the meaning and sources of joint ownership of IPs in general and copyrights

\footnotetext{
${ }^{1}$ See Article 826(2) of the Ethiopian civil code. Not only rights but also obligations of the deceased persons, which are not terminated up on the death of the deceased passes to his/her heirs or legatees. For the distinction between inheritable and un-inheritable rights, see infra note 27. ${ }^{2}$ John W. Salmond(1947), cited at note 2 p. 451.

${ }^{3}$ Ibid. Salmod, speaking of the common law rule on inheritance, states that "In respect of the death of their owner all rights are divisible into two classes, being either inheritable or un-inheritable. A right is inheritable, if it survives its owner; un-inheritable, if it dies with him. This division is to a large extent, though far from completely, coincident with that between proprietary and personal rights. The latter are in almost all cases so intimately connected with the personality of him in whom they are vested, that they are incapable of separate and continued existence."

${ }^{4}$ See Article 2(16), 8 and 20(1) of the copyright proclamation

${ }^{5}$ See Article 6 of the patent proclamation

6 The Commercial Code Proclamation, 1960, Proc. No.166, Negarit Gazzete, $19^{\text {th }}$ year No.3 Article 127(2)

${ }^{7}$ Id. Article 171

${ }^{8}$ Id. Article 189

${ }^{9}$ Dagnachew Worku, 'Valuation and Commercialization of Intellectual Property Rights in Ethiopia' (LLM Thesis: Addis Ababa University, College of Law and Governance Studies: School of Law 2016) p.58. available at < https://scholar.google.com/scholar?q=dagnachew+worku++valuation+and+commercialization\&hl=en\&as_sdt=0\&as_vis=1\&oi=scholart> last accessed April 12,2020
} 
and patents in particular under the Ethiopian laws have been discussed. In this section the meaning and types of exploitation of IPs in general and copyright and patents in particular will be discussed.

\subsection{The Meaning of IP Exploitation}

Under the World Intellectual Property Organization (WIPO) glossary of terms in the field of copyright and neighboring rights, exploitation of work is explained as 'the use of a work for profit-making purposes by exhibiting, reproducing, distributing or otherwise communicating it to the public.' ${ }^{1}$ Two things that can easily be inferred from the given explanation are: 1) exploitation of work is understood to be solely for profit making purposes, 2) the explanation seems to suggest only direct exploitations as indirect exploitation such as granting license on the work is not included here.

Exploitation of IPRs needs to be understood broadly so as to encompass both commercial and noncommercial and direct and indirect exploitation of the IPRs as well as the ever growing possibilities of making use of IPRs which the current technological advancement has handed to us.

Generally exploitation of IPs in general and copyright and patents in particular can broadly be defined as 'everything related to the use, sale, marketing, advertising, technology transfer, licensing and other activities that may generate an economic return for the owners, based on IPRs.' ${ }^{2}$ The exploitation of IPRs might be by a single person or by more than one person.

\subsection{Types of IP Exploitations}

Intellectual property rights can be exploited either directly or indirectly by the owner of the rights. Intellectual property confers the right to exclude others from exploiting the protected intangible subject matter. ${ }^{3}$ Except where the law imposes a limitation on the owner of the intellectual property rights, third parties cannot exploit such rights without the authorization of the owner. Accordingly, the owner of intellectual property rights can exploit the right $\mathrm{him} /$ herself (directly) or through the agency of third parties (indirectly). The owner of an IP exploits the right indirectly when he/she authorizes third parties to exploit the right up on payment of the agreed amount of compensation/royalties to the owner of the right.

The manner of exploitations available with respect to a particular intellectual property right varies depending on the particular nature of such rights. The laws in the area of each intellectual property right provides for acts amounting to the exploitation of the rights concerned. Consequently, the method of exploitation of a copyright differs from that of patent and trademarks.

In this regard Article 7 of the copyright proclamation has provided a lists of acts which can be carried out exclusively or through the authorization of author or owner of the work in the exploitation of a copyright such as reproduction, translation, adaptation, arrangement or other transformation of the work, distribution of the original or a copy of the work to the public by sale or rental, importation of original or copies of the work, public display of the original or a copy of the work, performance of the work, broadcasting of the work, other communication of the work to the public. Accordingly, carrying out either one or more of the aforementioned act constitutes exploitation of a copyright.

On the other hand, the patent proclamation under its Article 22 provides for the exclusive rights of a patentee such as the right to make, use or otherwise exploit the patented inventions. Exploitation in the context of a patent, therefore, is making, using or otherwise exploiting the patented invention.

In both cases exploitation might be by the owner of the copyright or patent him/herself or by a third party through authorization of the owner. Moreover, since both the copyright and patent proclamation have not made distinction on the basis of the purpose for which such rights can be used for, the exploitation in both cases might be either for commercial (profit making) or for non-commercial (personal use) purposes.

\section{Section Three: Rules for the Exploitation of Jointly Owned IPRs}

In this section of the work, rules for the exploitation of jointly owned IPs particularly copyright and patents will be explored under the Ethiopian laws in light of the experiences of some other jurisdictions.

Since joint ownership of IPs necessarily involves more than one person, rules for the exploitation of such rights either by one of the joint owners or jointly by all of them while keeping the joint ownership intact is imperative. Having a default rules especially where the joint owners of IP have failed to agree on how to exploit such rights are of paramount importance for the fair utilization of the rights by the joint owners on the one hand and efficient utilization of the rights for the national economy on the other.

\footnotetext{
${ }^{1}$ WIPO Glossary of Terms of the Law of Copyright and Neighboring Rights, Published by the World Intellectual Property Organization, Geneva 1983. pp.108 available at $<$ https://www.wipo.int/publications/en/details.jsp?id=3637\&plang=EN $>$ last accessed April 2,2020.

${ }^{2}$ Juliana Moncaleano(2017), Value generation from the exploitation of intellectual property, Clarke, Modet \& co- Colombia

$<$ https://www.mondaq.com/Intellectual-Property/596808/Value-Generation-from-the-Exploitation-of-Intellectual-Property $>$ last accessed March 29, 2020.

${ }^{3}$ Roger E. Schechter and John R. Thomas cited at note 13, p.5
} 
In principle, the joint owners are at liberty to determine the rules/ manner of exploitation of their jointly hold rights. As discussed in the preceding sections of this work, one of the sources of joint ownership of IPs is agreement either at the time of the creation of the work or through subsequent transfer of the work to more than one person. Joint owners, through their agreement, may determine starting from the share each of them have on the jointly owned IP to the manner of exploiting every rights which the joint ownership brought about.

On top of the ownership proportions held by each joint owner, the joint owners, in their agreement, have to address the following three critical questions with respect to the exploitation of the jointly owned IPs. ${ }^{1}$

1) Whether a joint owner can exploits the jointly owned intellectual property only with, or without the need for, the other joint owner's consent? Or only with the obligation, or without the obligation, to pay royalties (or other fees)?

2) Whether a joint owner can grant a license of the jointly owned intellectual property to another person only with, or without the need for, the other joint owner's consent? Or only with the obligation, or without the obligation, to share the royalties (or other fees) received from the licensee?

3) Whether a joint owner can assign its share of the jointly owned intellectual property to another person only with, or without the need for, the other joint owner's consent?

Where joint owners are failed or unable to reach in to an agreement on how to exploit the jointly owned IPRs, the law steps in and provide for default rules for the exploitation of jointly owned IPRs. Next is a brief discussion of how the laws of some states have treated the rules for exploitation of jointly owned copyright and patent in the absence of agreement among the joint owners.

\subsection{The Experiences of Other States}

The following is a discussion on the default rules of some jurisdictions regarding the exploitation of jointly owned copyright and patent where the joint owners have failed or unable to reach in to an agreement on how to exploit the jointly owned copyrights and patents.

\section{a) USA}

Regarding the exploitation of jointly owned patents, in the absence of an agreement to the contrary, the default rules in USA is that each of the joint owners of a patent may make, use, offer to sell, or sell the patented invention within the United States, or import the patented invention into the United States, without the consent of and without accounting to the other owners. ${ }^{2}$ Accordingly, each co-owner may independently exploit, without consent of, and without accounting to, the other co-owners.

On the other hand in a jointly owned of copyrights, each joint owners can independently exploit, but must account profits to other co-owners. ${ }^{3}$ Accordingly, each joint owners of the copyright has the right to use the work, prepare derivative works based on it, perform it, display it, and so forth, without seeking the other coauthor's permission. However, if profits arise out of such uses, an accounting must be made so that each author shares in the benefits or proceeds. The joint owner may grant non-exclusive license to another party to use the joint work or may sell his or her own interest in the copyrighted work without permission from the other coauthors. ${ }^{4}$ However, granting an exclusive license and assignment of all interest in the work requires the consent of all co-owners. ${ }^{5}$

\section{b) France}

Under the French intellectual property code, joint owners of a patent may not grant license to a third party without consent of the other co-owners, but may independently use the invention, each with equitable compensation to the other co-owners who have not (directly or indirectly) exploited the invention themselves. ${ }^{6}$ On the other hand the consent of all co-owners is required for the exploitation of jointly owned copyright by each of the joint owners in addition to an accounting of profits per the consent. ${ }^{7}$

\section{c) Japan}

Under the Japan patent act, joint owner of a patent is not allowed to assign his/her share on the jointly owned patent or to grant license( both exclusive and non-exclusive) to a third parties nor to pledge the patent without the consent of all other joint owners. ${ }^{8}$ Unless otherwise agreed up on by the contract, each of the joint owners of the patent right may work the patented invention without the consent of the other joint owners and without the need to account to the other joint owners. ${ }^{9}$

\footnotetext{
${ }^{1}$ Queensland Business, Your rights as a joint owner of intellectual property, Available at $<$ https://www.business.qld.gov.au/runningbusiness/protecting-business/ip-kit/browse-ip-topics/your-rights-as-a-joint-owner-of-intellectual-property> last accessed April 3, 2020

${ }^{2}$ see 35 U.S. Code. Sec. 262. Available at $<$ https://www.law.cornell.edu/uscode/text/35/262 > last accessed April 06,2020

${ }^{3}$ Deborah E. Bouchoux, cited at note 16 pp. 230

${ }^{4}$ Ibid.

${ }^{5}$ Ibid.

${ }^{6}$ See Art. L613-29 of the French Intellectual Property Code available at< https://internet-law.ru/ int / france> last accessed April 10, 2020.

${ }^{7}$ Id. Art. L113-3

${ }^{8}$ See Article 73 of the Japan Patent Act (Act No.121, 1959) available at $<$

www.japaneselawtranslation.go.jp/law/detail/?printID $=\& \mathrm{ft}=1 \& \mathrm{co}=01 \& \mathrm{x}=32 \& \mathrm{y}=19 \& \mathrm{ky}=\% \mathrm{E} 7 \% 89 \% \mathrm{~B} 9 \% \mathrm{E} 8 \% \mathrm{~A} 8 \% \mathrm{~B} 1 \% \mathrm{E} 6 \% \mathrm{~B} 3 \% 95 \& \mathrm{page}$ $=10 \& i d=42 \& l v m=\& r e=02 \& v m=02>$ last accessed May 2,2020 .

${ }^{9}$ Ibid.
} 
As per the Copyright Act of Japan, a joint owner of a copyright may not exploit the copyright without the consent of all other joint owners. ${ }^{1}$

A brief discussion made above regarding the experiences of some jurisdictions such as USA, France and Japan tells us that rules for the exploitation of jointly owned IPs are primarily left to be determined by the joint owners through agreement. These states have provided a default rules under their IP laws for the exploitation of IPs where the joint owners have either failed or unable to reach in to an agreement. This being the situation in those states, the following will be an examination of rules for the exploitation of jointly owned IPs particularly copyright and patent in Ethiopia.

\subsection{Rules for the Exploitation of Jointly Owned Copyrights and Patents in Ethiopia}

As discussed in the preceding sections of this work, the Ethiopian copyright and patent laws have recognized joint ownership of copyrights and patents respectively. The purpose of the current section is to examine rules for the exploitation of such jointly owned patents and copyrights in Ethiopia.

Primacy in determining how to exploit the jointly owned copyrights and patents is given to the agreement of the joint owners. The joint owners can determine, through agreement, the ownership proportion each of them has in a jointly owned copyright and patents. The agreement of the joint owners, if there is any, is expected to address the three questions raised above with respect to the exploitation of such jointly owned IPs.

The Ethiopian Copyrights and patent proclamation, even though they have recognized joint ownership of copyrights and patents, have not provided a default rules for the exploitation of such jointly owned copyrights and patents where the joint owners have failed or unable to reach in to an agreement on how to exploit such jointly owned copyright and patents. ${ }^{2}$ Nor do they make an explicit reference to the provisions of the civil code of Ethiopia on joint ownership of property to be applicable to the jointly owned of copyrights and patents. However, it can be argued that the Ethiopian Copyrights Proclamation have made an implied reference to the provisions of the civil code on joint ownership. ${ }^{3}$ The patent proclamation, on the other hand, has neither explicit nor implied reference to any other laws in this regard.

Even though, both the copyright and patent laws of Ethiopia are failed to provide for the default rules on how jointly owned copyright and patents are to be exploited in the absence of an agreement among the joint owners, the mutatis mutandis application of the provisions of the civil code on joint ownership of property is suggested. ${ }^{4}$ Since intellectual properties are one category of property rights, it is also the opinion of the author of this work that the provisions of the civil code of Ethiopia on joint ownership, to the extent possible, should be applicable as a default rule for the exploitation both of jointly owned copyrights and patents in the absence an agreement among the joint owners. On the other hand the application of the provisions of the civil code of Ethiopia on joint ownership to the jointly owned intellectual property in general and jointly owned copyright and patent in particular is of pragmatic importance. This is because courts cannot refuse to decide on cases brought before them regarding the jointly owned copyright or patent on the ground that there is no law in that regard. Accordingly, where courts are faced with disputes regarding the exploitation of jointly owned copyrights and patents, where else can they look for a solution other than resorting in to the provisions of the civil code of Ethiopia on joint ownership of things? This does not; however, mean that the application of the provisions of the civil code of Ethiopia on joint ownership could resolve every issue in relation to the exploitation of jointly owned copyrights and patents but they can at least provides us the basic principles on joint ownership. This can also help in resolving at least some of the issues on exploitation of jointly owned copyrights ${ }^{5}$ and patents (this will be elaborated further subsequently).

As discussed above, the experiences of some states shows that while priority is given to the agreement of the joint owners, default rules for the exploitation of copyright and patents are provided under their copyright and patent laws. On the other hand the experiences of other states (especially those from civil law legal system) shows that in the absence of an agreement among the joint owners and where their IP laws failed to provide for default rules or makes cross-reference to their respective civil code, the civil code provisions on joint ownership serves as

\footnotetext{
${ }^{1}$ See Article 65 and 117 of Japan Copyright Act (Act No.48, 1970) available at $<$ https://en.m.wikisource.org/wiki/> last accessed May 2, 2020.

${ }^{2}$ Elias N. Stebek and others, Property Rights Protection and Private Sector Development in Ethiopia (Private Sector Development Hub, Ethiopian Chamber of Commerce and Sectoral Associations, 2013 ) p.36, see also Dagnachew Worku Gashu, 'Examining the Legal Regime Governing Commercialization of Patents, Copyrights and Trademarks in Ethiopia' [2018] Developing Country Studies Vol.8, No.1 p.2 available at $<$ https://www.iiste.org/Journals/index.php/DCS/article/view/40592> last accessed April 3, 2020.

${ }^{3}$ This can be inferred from the repealing clause (Article 38) of the Ethiopian Copyrights and Neighboring Rights Protection Proclamation No.410/2004 which states "Any other law, which is inconsistent with this Proclamation, shall not be applicable with respect to matters provided for in this Proclamation." Other laws are still applicable on matters not covered under the proclamation and even for matters covered under the proclamation, which are not inconsistent with the proclamation. One of the matters not covered under the proclamation is default rules for the exploitation of jointly owned copyrights. Accordingly, there is a possibility that other laws such as the provisions of the civil code on joint ownership could be applicable to the exploitation of jointly owned copyrights.

${ }^{4}$ Fikremarkos Merso, The Ethiopian Law of Intellectual Property Rights: Copyrights, Trademarks, Patents, Utility Models and Industrial Designs, A Textbook (Addis Ababa: The American Bar Association, 2012) p.97

${ }^{5}$ Elias N. Stebek et al cited at note 47, p.36
} 
a default rule for the exploitation of jointly owned IPs. Italy and Spain can be taken as an example in this regard. Regarding jointly owned patents, in the absence of an agreement of the joint owners and in default of the patent laws, the joint ownership provisions of the civil code of both Italy and Spain are made applicable to the jointly owned patents. ${ }^{1}$

Assuming that the governing legal regime for jointly owned patents and copyrights in Ethiopia, in the absence of an agreement among the joint owners, are the provisions of the Ethiopian civil code on joint ownership (Article 1257-1277), the following is a discussion on the rules on exploitation of jointly owned copyrights and patents in Ethiopian. It should be noted, however, that those provisions are basically meant for joint ownership of tangible assets as the code repeatedly use the term 'thing' which is used interchangeably with goods. ${ }^{2}$ Accordingly, making some sort of adaptation (analogy) is a must in order to apply them to the jointly owned copyrights and patents.

It should also be made clear from the very outset that not all provisions of the code on joint ownership could be replaced by the agreement of the joint owners. Even though joint owners are at liberty to determine their rights and duties with respect to the jointly owned thing through an agreement, their agreement is subjected to the mandatory provisions of the laws. ${ }^{3}$ Accordingly, some of the provisions of the code on joint ownership are always applicable irrespective of the joint owners' agreement concerning the jointly owned things. ${ }^{4}$

Regarding the ownership proportion of each joint owner, in the absence of an agreement to the contrary, the presumption under the Ethiopian law regarding the ownership proportion of each joint owner is equality of share. ${ }^{5}$ The patent proclamation also recognizes equality of share, in the absence of an agreement to the contrary, in case of inventions resulting from both the personal contribution of the employee and the resources, data, means, materials or equipment of the employer. ${ }^{6}$ But the proclamation is failed to provide a default rule on presumption on the ownership proportion of joint owners of patents where such joint ownership arises from other modalities such as joint creation. So in all cases where the joint owners have failed to agree on their ownership proportion on the jointly owned copyrights and patents, the presumption of the law is equality of share.

In the following part of this work an attempt is made to answer the three questions posed earlier regarding the exploitation of jointly owned intellectual properties in general copyrights and patents in particular through the analysis of the provisions of the Ethiopian civil code on joint ownership.

1. Can a joint owner exploit the jointly owned copyright or patent only with, or without the need for, the other joint owner's consent; only with the obligation, or without the obligation, to pay royalties (or other fees)?

Both the copyright and patent proclamation has provided the types of exploitation available to the owner of copyright and patent. According to Article 7 of the copyright proclamation, the author (where the economic rights are vested in him/her) or the owner of copyright have the exclusive right to carry out or authorize: reproduction, translation, adaptation, arrangement or other transformation, distribution of the original or a copy of the work to the public by sale or rental, importation of original or copies , public display of !he original or a copy, performance , broadcasting, other communication of the work to the public.

On the other hand, the patent proclamation provides that the patentee has the exclusive right to make, use or otherwise exploit the patented invention. ${ }^{7}$ The patentee has also the exclusive right to authorize others to exploit the patented invention. ${ }^{8}$

Regarding the use of jointly owned rights by the joint owners, the Ethiopian civil code provides that "each joint owner may use the thing jointly owned in accordance with the purpose for which it is acquired and with due regard to the rights of the other joint owners. "' Each joint owner has the right to use the thing jointly owned (in our case IPR) with in the limit of the purpose for which such joint ownership of a copyright or patent came in to existence. At this juncture it imperative to ask the question, why the joint ownership of copyright or patent came

\footnotetext{
${ }^{1}$ European IPR Helpdesk, IP Joint Ownership, fact sheet 2015 available at $<$ www.iprhelpdesk.eu>

P.13-14 see also Article 6 of the Italian Code of Industrial Property, Legislative Decree $N^{\circ} 30$ of 10 February 2005(as amended) available at $<$ www.les-italy.org/en/category/publications $>$, which makes cross-reference to the provisions of the Italian civil code on joint ownership as a default rule for exploitation of jointly owned patents.

${ }^{2}$ Article 1126 of the Ethiopian civil code classifies goods, within the realm of tangible asset, as movable and immovable.

${ }^{3}$ Id. Article 1258(1)

${ }^{4}$ Such mandatory provisions includes: legal right of pre-emption (Art. 1261), the right to apply for partition of the jointly owned things and joint administration of the thing jointly owned (Art. 1264 and 1265) of the civil code of Ethiopia.

${ }^{5}$ Article 1259 of the civil code of Ethiopia

${ }^{6}$ Article 7(5) of the Patent proclamation

${ }^{7}$ See Article 22 of patent proclamation. It is not clear whether the term 'otherwise exploit' also includes the rights of patentee under the TRIPS Agreement such as to prevent third parties not having the owner's consent from the acts of 'offering for sale and selling or importing' the patented inventions. See Art.28.1 of the TRIPS Agreement. See also Elias N. Stebek et al (2013) Property Rights Protection and Private Sector Development in Ethiopia p.42. But it is the argument of the author of this work that the term 'otherwise exploit' should be interpreted to include the rights of a patentee recognized under the TRIPS Agreement (except the right to prohibit importation of a patented product which is clearly excluded under Article 22(2) of the same proclamation) because it seems that the legislature had deliberately used the term 'otherwise exploit' to incorporate other forms of exploitations which are not listed there.

${ }^{8}$ Ibid.

${ }^{9}$ See Article 1263 of the civil code of Ethiopia.
} 
in to existence? The purpose for which the joint ownership of the copyright or patent brought in to existence is situation based and we cannot have a single answer to the above question. Moreover, joint ownership of copyrights and patents may not necessarily result from the deliberate act of the joint owners as there are cases where such joint ownership arises even without the prior arrangement of the joint owners. One instance by which joint ownership of copyright or patent may come in to existence without the prior arrangement of the joint owners is the transfer of a copyright or patent to more than one person through inheritance.

Accordingly, the normal types of exploitation available with respect to a copyright or patent should be taken in to account in delineating the purpose for which such joint ownerships are created. So, each joint owner's right of using the jointly owned copyrights or patents for the purpose for which it is acquired needs to be understood as the normal use available with respect to the copyright (such as reproduction, translation, adaptation, arrangement or other transformation, distribution of the original or a copy of the work and so on) and patents (such as making, using or otherwise exploiting the patented invention).

Regarding the relationship between joint owners in using the jointly owned thing, the wording of the law saying 'with due regard to the rights of the other joint owners' implies that each joint owner, while using the jointly owned thing, should not violate the right of other joint owners of using that same thing. It is not necessary that one joint owner needs to get permission from others for using the jointly owned thing as long as he/she is using it in accordance with the purpose for which it is acquired and not depriving other joint owners' right of using the thing.

Bringing the idea in to the context of jointly owned copyrights and patents, each of the joint owners can exploit the jointly owned copyrights or patents, as long as he/she is not impeding the right of other joint owners, without seeking the consent of other joint owners. As discussed above, exploitation of an IPs may be direct or indirect. Intellectual property rights such as copyrights and patents could be exploited indirectly through granting license (exclusive or non-exclusive) to third parties to use such copyright or patent. Under the Ethiopian Copyright Proclamation, though no definition is provided for exclusive and non-exclusive license of copyright, the possibility of licensing a copyright either on the basis of exclusive or non-exclusive terms is implied. ${ }^{1}$ On the other hand the patent Proclamation has not expressly regulated the voluntary licensing of a patent right. However, it can be argued that the proclamation, though not with sufficient precision, has somehow recognized the possibility of voluntary licensing of a patent right by the patentee and this can be inferred from the wording of Article 22 of the proclamation which sates "... A third party cannot exploit the patented invention without securing the patentee's consent." Except in cases of involuntary (compulsory) licensing and other limitations imposed by the law ${ }^{2}$, every uses by third party of the patented invention is made dependent on the consent of the patentee. As far as the patentee has the right either to allow or forbid the use of the patented invention by a third party, he/she can require payment of royalties or fees from the third parties in consideration for allowing them use the patented invention thereby licensing the patent to third parties.

Coming back to the issue of granting license to a third party on a jointly owned copyrights or patents, each joint owners must seek the consent of the other joint owners before granting a license on such jointly owned copyright or patent to third parties. This is so because granting a license by one of the joint owners to a third party, even though such joint owner has a duty to account to the other joint owners, on a jointly owned copyright or patent can affect the interests of other joint owners. Even though the incomes and profits that could be derived from the licensing of a jointly owned copyright and patent by one of the joint owners is to be shared ultimately among all joint owners, each joint owners should have a say on the terms and conditions up on which such license is to be granted to a third party. In case of disagreements among joint the owners regarding granting of license to a third party on a jointly owned copyright or patent; it has to be determined by the joint owners representing the majority of the share on a jointly owned copyright or patent. ${ }^{3}$ However, the law has said nothing on how disagreements to be resolved in cases where joint owners representing equal share on a jointly owned thing on both sides disagree on the administration of the jointly owned things.

The other issue of paramount importance regarding the exploitation of jointly owned copyrights and patents is whether each joint owner has an obligation to share with other joint owners the profits/income derived from the exploitation of such copyrights or patents. The position of the Ethiopian civil code in this regard is that the fruits of a thing jointly owned are also jointly owned. ${ }^{4}$ Accordingly, it can be said that every income and profits derived from the jointly owned copyright and patent, to the extent they can be identified as the fruits of such jointly owned copyrights and patents, should be shared among the joint owners. Each joint owners have the right to have a share on such incomes and/profits in proportion to their share on the jointly owned copyright and patent despite the fact that the incomes and/profits have been generated by any one of the joint owners. A joint owner is supposed to share with other joint owners profits and/incomes derived from the commercial exploitation of jointly owned

\footnotetext{
${ }^{1}$ See Article 23-25 of the copyright proclamation

${ }^{2}$ See Articles 25, 26, 29 to 33 of the patent proclamation

${ }^{3}$ See Article 1265 of the Ethiopian civil code

${ }^{4}$ Id. Article 1264(1)
} 
copyrights and patents. ${ }^{1}$ Accordingly, each joint owner can exploit the jointly owned copyright or patent for personal use (non-commercial purpose), as long as such exploitation has not impaired the rights of other joint owners and are in line with the purpose for which such rights can be used for, without the need to secure the consent of other joint owners and without the duty to account for such uses to other joint owners. The joint owner who has incurred costs and expenses in generating the incomes and /profits from the jointly owned copyright and patent is entitled to reimbursement of such costs and expenses. ${ }^{2}$

2. Can a joint owner grant a license of the jointly owned copyright or patent to another person only with, or without the need for, the other joint owner's consent? Or only with or without the obligation, to share the royalties (or other fees) received from the licensee?

As discussed above, a joint owner cannot grant a license on a jointly owned copyright or patent to a third party without the consent of other joint owners. Joint owner granting a license to third party on a jointly owned copyright and patent, even with the consent of other joint owners, has an obligation to share the incomes and/profits derived from such licensing to the other joint owners.

3. Can a joint owner assign its share of the jointly owned copyright or patent to another person only with, or without the need for, the other joint owner's consent?

Each joint owner has the right to sale/assign or pledge his/her share on the jointly owned thing to a third party without the consent of other joint owners. ${ }^{3}$ The share each joint owner has on a jointly owned thing is to be determined either by the agreement of the joint owners or by the presumption of the law where the joint owners have failed to determine it through their agreement. As discussed previously, the law presumes equality of share in the thing jointly owned in the absence of an agreement among the joint owners to this effect. However, the other joint owners have the right to compel any third party who acquires a share in the thing jointly owned to sell it them. ${ }^{4}$

In a similar fashion, the joint owner of a copyright or patent has the right to assign/sale his/her share on a jointly owned copyright or patent to another person without the consent other joint owners. However, the copyright and patent laws of Ethiopia are silent on the issue of whether or not the owners of copyright or patent can pledge their right as a security for the performance of an obligation. Nor does the Ethiopian civil code in its relevant part addressed rules for the formation of security interest on IPRs. ${ }^{5}$ Accordingly, on the face of the absence of legal rules for securitization of IPRs, it is difficult to say that a joint owner of copyright or patent can pledge his/her share on such jointly owned copyright or patent.

Finally, regarding the administration of things jointly owned, the rule under the Ethiopian civil code is that all joint owners shall have a say on the administration of such jointly owned things. ${ }^{6}$ Where decisions regarding such things are to be made, such decisions are to be made by majority of the joint owners representing majority of share on a jointly owned things. ${ }^{7}$ The rules on administration of jointly owned things under the civil code of Ethiopia should also be extended to the administration of the jointly owned copyrights and patents. Accordingly, decisions on the administration of jointly owned copyrights and patents should be taken by majority of the joint owners representing majority of the shares on jointly owned copyright or patent. On the other hand unanimous consent of all joint owners is required for the disposal (sale) of the jointly owned copyright or patent in its totality. ${ }^{8}$

\section{Section Four: Conclusions and Recommendations}

\subsection{Conclusions}

Joint ownership is a situation whereby two or more persons shares undivided interest in a property (including intellectual properties). It could arise either through the provisions of the law or contractual agreements among the joint owners. In some cases juridical acts such as wills can also be a source of joint ownership where such rights are transferred to two or more persons through inheritance. In principle, the joint owners of a copyright and patent are at liberty to determine the manner of exploiting the jointly owned copyright or patent through their mutual

\footnotetext{
${ }^{1}$ Distinction should be made between the commercial and non-commercial exploitation of the jointly owned copyright or patent. Commercial exploitations are meant to bring about profits and /incomes( in our case fruits) either through sale, rental, distribution, public display and so on in case of copyrighted work and through sale of patented invention or granting license to third parties to use or to make the patented invention in case of patent. Non-commercial (personal) exploitations of the jointly owned copyright and patent, on the other hand, are the personal uses (consumptions) of the jointly owned copyrighted work (e.g. watching a film or copying a book for the purpose of reading by the joint owners) or the jointly owned patent (e.g. personal use of a product of patented invention by the joint owners of the patent).

${ }^{2}$ See Article 1267 cum 1270 of the Ethiopian civil code. While costs incurred in relation to administration, taxes and pledging or mortgaging the thing jointly owned are to be shared by all joint owners in proportion to their share, a joint owner who has incurred an expense in the production or collection of the fruits is entitled to deduct such expenses before the proceeds from such fruits are divided among the joint owners. ${ }^{3}$ Id. Article 1260 cum 1266, Unlike the sale of jointly owned thing in its totality, which requires the unanimous consent of all joint owners, the sale of a joint owner's share on a jointly owned thing does not requires the consent of other joint owners.

${ }^{4}$ Id. Article 1261

${ }^{5}$ Dagnachew Worku, cited at note 33, p.58.

${ }^{6}$ See Article 1265 of the Ethiopian civil code

${ }^{7}$ Ibid.

${ }^{8}$ Id. Article 1266
} 
agreement. The law steps in only where the joint owners are failed to determine the manner of exploitation of jointly owned copyright or patent through their agreement. The Ethiopian copyright and patent laws, while recognizing the possibility of joint ownership of copyright and patent respectively, are failed to provide for default rules for the exploitation of such rights by the joint owners where the latter either failed or unable to reach in to a mutual agreement to this effect. Nor do they make an explicit reference to the provisions of the Ethiopian civil code on joint ownership for their applicability to the jointly owned copyrights and patents.

In the absence of default rules under the copyright and patent laws and an agreement among the joint owners for the exploitation of jointly owned copyrights and patents, the provisions of the Ethiopian civil code on joint ownership shall be applicable mutatis mutandis to the jointly owned copyright and patent. This is of pragmatic importance as courts cannot refuse to entertain and decide on cases brought before them in relation jointly owned copyright and patent on the ground that there are no legal rules in this respect.

Since the provisions of the Ethiopian civil code on joint ownership are basically meant to govern tangible property (things), a modification of some sort is a must to make them applicable to the jointly owned copyright and patent which are inherently intangibles. On the basis of such provisions, the ownership proportion of each joint owner on a jointly owned copyright and patent, in the absence of an agreement to the contrary, is presumed to be equal. Regarding the exploitation of jointly owned copyright or patent, each joint owner has the right to exploit the jointly owned copyright or patent without seeking permission from other joint owners as far as such exploitations have not impaired the rights of other joint owners. However, exploitations having the effect of impairing the rights of other joint owners such as granting a license on a jointly owned copyright and patent require the consent of other joint owners.

Each joint owner has the right to have a share on incomes and/profits derived from the jointly owned copyright or patent in proportion to their share on the jointly owned copyright and patent despite the fact that the incomes and/profits have been generated by any one of the joint owners. A joint owner who has incurred costs and expenses in generating the incomes and /profits from the jointly owned copyright and patent is entitled to reimbursement of such costs and expenses.

While each joint owner has the right to assign his/her shares on a jointly owned copyright or patent without the consent of other joint owners, the assignment of the right in its totality requires the unanimous consent of all joint owners.

The joint owners' joint action is required for the administration of jointly owned copyrights and patents. Where decisions are to be made regarding the jointly owned copyright or patents, such decisions shall be taken by majority of vote of owners representing a majority share on the jointly owned copyrights or patents. However, the law has not provided how decisions are to be made where joint owners representing an equal share on jointly owned rights on both sides are failed to reach in to an agreement.

\subsection{Recommendations}

As discussed above, the Ethiopian copyright and patent laws have not provided default rules for the exploitation of jointly owned copyright and patent in the absence of an agreement among the joint owners nor do they make an explicit reference to the provisions of the Ethiopian civil code on joint ownership to be applicable to jointly owned copyright and patents. It has also been stated that the provisions of the Ethiopian civil code on joint ownership are basically meant to govern physical objects (things) and that makes the direct application of such provisions to the jointly owned copyrights and patents problematic. The mutatis mutandis application of the provisions of the Ethiopian civil code on joint ownership of things, in the absence of an agreement among the joint owners, to the jointly owned copyright and patent as a default rule has been argued for in this work as a last resort. Even in that case, all issues that could arise on exploitation of jointly owned copyrights and patents cannot be resolved. Accordingly the writer of this work recommends:

The revision of the Copyright and patent Proclamations so as to include default rules for the exploitation of jointly owned copyrights and patents respectively. The revision of such laws should particularly regulate 1) the nature and quality of contribution necessary to consider such contributor as a joint creator of a work thereby joint owner of the resulting works/inventions, 2) the role of joint owners' intention in creating the a joint works/inventions 3) the presumption on ownership proportion of each joint owner on a jointly owned copyrights and patents; 4) the extent of each joint owner's right to exploit the jointly owned copyright and patents without the need to get the consent of others; 5) exploitations which requires the consent of all or majority of the joint owners; 6) the manner of sharing incomes /profits/royalties derived from the jointly owned copyright and patent and costs and expenses incurred in the administration of such rights among the joint owners; 7) the administration of jointly owned copyright and patents by joint owners and how decisions are to be taken with respect to such rights especially where joint owners representing equal share on a jointly owned copyright and patent failed to reach in to an agreement; and 8) enforcement of the right by joint owners( individually or collectively) in case of infringement of jointly owned copyright and patents. 


\section{Lists of References}

$>$ Bryan A. Garner (ed.) Black's Law Dictionary ( $9^{\text {th }}$ edn, Thomson Reuters 2009)

$>$ Copyright and Neighboring Rights Protection Proclamation,2004, Proc.No.410, Federal Negarit Gazzeta, $10^{\text {th }}$ year No.55

$>$ Dagnachew Worku Gashu, 'Examining the Legal Regime Governing Commercialization of Patents, Copyrights and Trademarks in Ethiopia' [2018] Developing Country Studies Vol.8, No.1available at $<$ https://www.iiste.org/Journals/index.php/DCS/article/view/40592> last accessed April 3, 2020.

$>$ Dagnachew Worku, 'Valuation and Commercialization of Intellectual Property Rights in Ethiopia' (LLM Thesis: Addis Ababa University, College of Law and Governance Studies: :School of Law 2016) available at $<$ https://scholar.google.com/scholar?q=dagnachew+worku++valuation+and+commercialization\&hl=en\&as_ sdt $=0 \&$ as_vis $=1 \&$ oi $=$ scholart $>$

$>$ Deborah E. Bouchoux, Intellectual Property: The Law of Trademarks, Copyrights, Patents, and Trade Secrets $\left(4^{\text {th }}\right.$ edition Delmar, Cengage Learning 2012)

$>$ Elias N. Stebek and others, Property Rights Protection and Private Sector Development in Ethiopia (Private Sector Development Hub, Ethiopian Chamber of Commerce and Sectoral Associations, 2013 )

$>$ European IPR Helpdesk, IP Joint Ownership, fact sheet 2015 available at $<$ www.iprhelpdesk.eu>

$>$ Fikremarkos Merso, The Ethiopian Law of Intellectual Property Rights: Copyrights, Trademarks, Patents, Utility Models and Industrial Designs, A Textbook (Addis Ababa: The American Bar Association, 2012)

$>$ French Intellectual Property Code available at $<$ https://internet-law.ru/int/france $>$ last accessed April 10, 2020.

$>$ Japan Copyright Act (Act No.48, 1970) available at $<$ https://en.m.wikisource.org/wiki/> last accessed May $2,2020$.

$>$ Japan Patent Act (Act No.121, 1959) available at $<$ www.japaneselawtranslation.go.jp/law/detail/?printID $=\& \mathrm{ft}=1 \& \mathrm{co}=01 \& \mathrm{x}=32 \& \mathrm{y}=19 \& \mathrm{ky}=0 \mathrm{E} 7 \% 89 \% \mathrm{~B} 9 \% \mathrm{E}$ 8\%A8\%B1\%E6\%B3\%95\&page=10\&id=42\&lvm=\&re=02\&vm=02> last accessed May 2, 2020.

$>$ John W. Salmond, Jurisprudence or The Theory of The Law (10th ed. Stevens \& Haynes London 1902)

$>$ Juliana Moncaleano, 'Value Generation from the Exploitation of Intellectual Property' Clarke, Modet \& coColombia $2017<$ https://www.mondaq.com/Intellectual-Property/596808/Value-Generation-from-theExploitation-of-Intellectual-Property> last accessed April 29,2020.

$>$ Proclamation Concerning Inventions, Minor Inventions and Industrial Design, 1993, proc.No.123, Negarit Gazzeta, $54^{\text {th }}$ year No. 25

$>$ Roger E. Schechter and John R. Thomas, Intellectual Property: the Law of Copyrights, Patents and Trademarks (Hornbook Series, West Group 2003)

$>$ The Civil Code of The Empire of Ethiopia, 1960, Proc. No.165, Negarit Gazzeta, $19^{\text {th }}$ year No.2

$>$ US Copyright Act (1976) available at < https://codes.findlaw.com/us/title-17-copyrights/17-usc-sect101.html > last accessed April 14, 2020.

$>$ WIPO Glossary of Terms of the Law of Copyright and Neighboring Rights, Published by the World Intellectual Property Organization, Geneva 1983.< available at < https://www.wipo.int/publications/en/details.jsp?id=3637\&plang=EN > last accessed April 2,2020.

$>$ The Commercial Code Proclamation, 1960, Proc. No.166, Negarit Gazzete, $19^{\text {th }}$ year No.3 